\title{
The KT Jeang Retrovirology Prize 2020: call for nominations
}

\author{
Susan R. Ross' ${ }^{1}$ Johnson Mak ${ }^{2}$ and Ariberto Fassati ${ }^{3^{*}}$
}

The Retrovirology prize was initiated by our founding Editor Kuan-Teh Jeang (Teh). In his 2005 editorial (Retrovirology 2005 2:26), Teh argued that there were few prizes dedicated to the "silent majority" of mid-career scientists whereas prizes for younger or older colleagues were numerous. He concluded that a prize honouring the achievements of colleagues in the 45-60 age bracket in the field of Retrovirology would fill an important niche, and so the prize was started with a generous philanthropic donation from Kuan-Chen Jeang (who is also the sibling of Teh). After the untimely passing of Teh, the prize was renamed the KT Jeang Retrovirology prize to honour Teh's contribution to our field. A total of 13 outstanding scientists have been awarded with Retrovirology Prize since its inception, and the full list is available here (https://www.biomedcentral.com/collections/retrovirol ogy-prize). The achievements of our awardees have been described in the editorials that accompany the official announcement of the winner in the journal.

During the early years of Retrovirology Prize, nominations were initiated by our Associate Editors, which was subsequently extended to members of our editorial board to better reflect the wider community of our discipline. The voting process was carried out by secret ballot cast by the Associate Editors. Despite our good intentions, we now realize that there are areas of improvement that can be made to this process, to better reflect the diversity of our research community.

Therefore, in consultation with our Associate Editors, Susan Ross, Johnson Mak and I have established a new
Retrovirology Prize committee of 12 members, consisting of 6 females and 6 males based in different regions of the world, to provide a fantastic pool of expertise (see below). Members of this committee include past awardees and individuals who are outside of the Retrovirology Editorial team. Appointment to this committee will be for 3 years and committee members cannot be nominated for the award during their tenure as assessors of the Retrovirology Prize. To maintain the original spirit of Retrovirology Prize, all applications will be assessed and scored based on the merit of the applicants' demonstrated scientific accomplishments. We have also changed the nomination process to be more inclusive; nominations, including selfnominations, are open to anyone, please follow this link for instructions on how to nominate https://retrovirol ogy.biomedcentral.com/about/retrovirology-prize.

One may ask why do we need a Retrovirology prize. One reason is to celebrate our champions and help them become role models for the younger generations. Another reason is to remind ourselves of key discoveries in the field and who made them. We all "stand on the shoulder of giants" but we all too often forget, in our preoccupation to see far into the distance, to take a look at those "giants" themselves. Yet another reason is to stir the community. In considering our colleagues' work, who might deserve the prize and why, we benefit our community by forcing all of us to take stock and think, discuss and persuade others. So please consider nominating a deserving colleague for the KT Jeang Retrovirology Prize. 
KT Jeang Retrovirology Prize: the new committee

\begin{tabular}{lll}
\hline Name & $\begin{array}{l}\text { Member } \\
\text { of Retrovirology } \\
\text { Editorial Board }\end{array}$ & Location \\
\hline Karen Beamon & No & USA \\
Monsef Benkirane & Yes & France \\
Ben Berkhout & Yes & Netherlands \\
Seph Borrow & Yes & UK \\
Carol Carter & No & USA \\
Michael Emerman & No & USA \\
Ari Fassati (chair) & Yes & UK \\
Masahiro Fujii & Yes & Japan \\
Thumbi Ngund'u & Yes & South Africa \\
Monique Nijhuis & Yes & Netherlands \\
Leslie Parent & Yes & USA \\
Susan Ross & Yes & USA \\
\hline
\end{tabular}

\section{Authors' contributions}

AF drafted the manuscript; SRR and JM reviewed and edited the draft. All authors read and approved the final manuscript.

\section{Competing interests}

The authors declare that they have no competing interests.

\section{Author details}

1 Department of Microbiology and Immunology, University of Illinois College of Medicine at Chicago, 835 S Wolcot Rm E703 MC790, Chicago, IL 60612-7342, USA. ${ }^{2}$ Institute of Glycomics, Griffith University, Gold Coast Campus, Parklands Drive, Southport, QLD 4222, Australia. ${ }^{3}$ Division of Infection \& Immunity, The Rayne Institute, University College London, 5 University Street, London WC1E 6BT, UK

Received: 9 December 2019 Accepted: 11 December 2019

Published Online: 10 February 2020

\section{Publisher's Note}

Springer Nature remains neutral with regard to jurisdictional claims in published maps and institutional affiliations.
Ready to submit your research? Choose BMC and benefit from:

- fast, convenient online submission

- thorough peer review by experienced researchers in your field

- rapid publication on acceptance

- support for research data, including large and complex data types

- gold Open Access which fosters wider collaboration and increased citations

- maximum visibility for your research: over 100M website views per year

At $\mathrm{BMC}$, research is always in progress.

Learn more biomedcentral.com/submissions 